\title{
O Oito de Março no Congresso: representações da condição feminina no discurso parlamentar*
}

\author{
Luiz Augusto Campos ** \\ Luís Felipe Miguel $^{* * *}$
}

\begin{abstract}
Resumo
Estudar as representações sobre as questões de gênero no parlamento é observar um espaço fundamental para as lutas políticas feministas, mas onde são poucas as vozes femininas. É também buscar entender os limites impostos pelas próprias dinâmicas do campo político a determinadas pautas, dentre as quais podemos incluir as questões de gênero. Este artigo pretende discutir as representações dos deputados e das deputadas brasileiras em relação à mulher, através da análise das representações da condição feminina nos discursos proferidos no plenário da Câmara dos Deputados durante as sessões dedicadas ao Dia Internacional da Mulher entre 1975 e 2006.
\end{abstract}

Palavras-chave: Discurso Parlamentar, Representação Política, Gênero, 8 de Março.

\footnotetext{
" Recebido para publicação em julho de 2007, aceito em maio de 2008.

*** Mestrando em Sociologia, Universidade Federal do Rio de Janeiro. lascampos@gmail.com

**** Doutor em Ciências Sociais pela Unicamp, professor do Instituto de Ciência Política da Universidade de Brasília e pesquisador do CNPq.

lfelipemiguel@uol.com.br
}

cadernos pagu (31), julho-dezembro de 2008:471-508. 
O Oito de Março no Congresso

March $8^{\text {th }}$ in Brazilian Congress:

Representations of the Female Condition in Parliamentary Speeches

\begin{abstract}
Congress and its current representations about gender are crucial spaces in feminist political struggles, but where there are few female voices. In these spaces, we can observe the limitations that the dynamics of the political field impose on certain issues, including gender. This paper discusses how female and male members of congress make their representations about women, analyzing the representations of the female condition present in speeches made in the plenary assembly of Brazilian Chamber of Deputies, in the course of the sessions held on International Women's Day (March 8th), between 1975 and 2006.
\end{abstract}

Key Words: Parliamentary Speech, Political Representation, Gender, March $8^{\text {th }}$. 
Entre a certeza de que a situação da mulher passou por profundas transformações, com avanços significativos desde o início do século $\mathrm{XX}, e$ a constatação de que a velocidade das mudanças se reduziu - ou mesmo de que vivemos um momento de estagnação, com as desigualdades se mostrando renitentes -, encontramos uma pluralidade de discursos que se entrecruzam $e$ se chocam. ${ }^{1}$ Surge, então, um cenário ambíguo, onde convivem opiniões cautelosas ou mesmo pessimistas em relação ao estágio atual, mas entusiásticas em relação à profundidade dos avanços passados.

O significado do dia 8 de março, Dia Internacional da Mulher, tem sido alvo de discordâncias, no mínimo reveladoras, desses paradoxos. Se muitos afirmam que se trata de uma data de comemoração, quando não de uma exaltação despolitizada da "feminilidade", outros enfatizam seu papel de reforço a uma luta longe de estar vencida. Como afirma Eva Blay:

O dia 8 de março é dedicado à comemoração do Dia Internacional da Mulher. Atualmente tornou-se uma data um tanto festiva, com flores e bombons para uns. Para outros é relembrada sua origem marcada por fortes movimentos de reivindicação política, trabalhista, greves, passeatas e muita perseguição policial (Blay, 2001:601).

Estabelecido em 1910, através da proposta da militante socialista Clara Zetkin, o 8 de março foi ratificado pela ONU em 1977 como Dia Internacional da Mulher. Segundo Blay, a data não estaria ligada ao muito citado incêndio na Triangle Shirtwaist Company, tecelagem novaiorquina, que teria matado mais de 100

\footnotetext{
1 A montagem da base de dados contou com a valiosa colaboração de Andrea Azevedo Pinho, aluna do curso de graduação em Ciência Política da Universidade de Brasília. Agradecemos também as críticas e sugestões de Aline de Almeida Coutinho, Flávia Biroli, Rebecca Abers e Regina Dalcastagnè, que leram versões anteriores do texto, bem como das/os pareceristas anônimos de cadernos pagu.
} 
O Oito de Março no Congresso

mulheres em 1857. O incêndio, segundo a autora, teria acontecido somente em 1911, logo, após a proposta de Zetkin (Id. ib.). Controvérsias à parte, fica claro pela história de sua criação e pelo mito invocado recorrentemente que a data nasceu com um apelo político: o de marcar o início de uma luta. Sua transformação em mera ocasião comemorativa, em que empresas de eletrodomésticos veiculam anúncios em jornais e supermercados oferecem rosas às suas clientes, revela uma apropriação que espantaria (e consternaria) suas criadoras.

Optar por uma dessas representações sobre o estado da mulher na sociedade é autorizar ou desautorizar determinados projetos políticos de longo alcance. Por esse motivo, o campo político, em especial a política formal nas democracias representativas contemporâneas, se constitui como importante locus de observação para entender a dinâmica de algumas representações sociais, incluindo as representações sobre as questões de gênero.

Este artigo discute as representações dos deputados e das deputadas brasileiras em relação à mulher, com base numa ampla pesquisa empírica com discursos proferidos no plenário da Câmara dos Deputados durante o Dia Internacional da Mulher e durante as sessões solenes dedicadas ao tema. O período escolhido, - de 1975 (o Ano Internacional da Mulher, segundo a ONU) a 2006 - não remete somente à marcante data inicial, mas, sobretudo, porque a amostra inicial apontou para a quase completa ausência de discursos sobre o tema antes dela.

Os discursos são relevantes porque permitem colocar em questão os efeitos da ausência de representantes femininas no parlamento - sendo o campo político formal, como se sabe, uma das searas em que as mulheres alcançaram avanços medíocres -, porque sua incorporação à cidadania eleitoral não foi acompanhada, na maior parte do mundo, pela incorporação às esferas de representação política. De acordo com dados da InterParliamentary Union (IPU), de dezembro de 2006, o percentual médio de mulheres nos legislativos ao redor do mundo é de 
$16,9 \%$. No Brasil, em que as mulheres alcançaram os direitos políticos em 1932, permanecemos, ainda, abaixo dessa média.

Portanto, estudar o parlamento e as representações sobre as questões de gênero nele contidas é observar um espaço fundamental para as lutas políticas feministas, que, simultaneamente, possui poucas vozes femininas e se constitui como centro privilegiado de construção de sentido. É buscar o que se pensa sobre as questões femininas em indivíduos alheios a essa perspectiva - exceto por empatia - e, por isso mesmo, discutir se as diferenças de perspectiva entre homens $e$ mulheres são relevantes politicamente (Phillips, 2001).

Neste trabalho, é fundamental não desconectar o conceito de "representação política" do de "representação social". Em outros termos, enfatizamos que as visões sobre a realidade socialmente construídas e compartilhadas (representações sociais) possuem efeito de representação política, entedida em sentido estrito como a ação de falar por outro em arenas de decisão pública, após a autorização por meio de eleições. ${ }^{2} \mathrm{~A}$ difusão de uma determinada "representação social" na sociedade pode ter efeito de "representação política", não somente porque altera as preferências dos indivíduos e, destarte, sua opção eleitoral, mas principalmente porque tem impacto na agenda e debate públicos, facilitando a emergência de determinadas questões e direcionando o resultado de sua discussão. ${ }^{3}$

\section{Gênero como representação e gênero da representação}

Existem inúmeras interpretações sobre $\mathrm{o}$ peso das representações sociais nas diferenças entre homens e mulheres. Todavia, é possível tipificar tais visões em três tendências básicas. Primeiramente, o determinismo biológico, que considera as

2 Para maiores detalhes sobre o conceito de representação social, ver Jodelet (2001); sobre o conceito de representação política, ver Pitkin (1967).

3 Para uma discussão sobre as diferentes dimensões da representação política, ver Miguel (2003). 
O Oito de Março no Congresso

diferenças de gênero epifenômenos da constituição biológica dos corpos. A segunda se refere ao chamado "fundacionalismo biológico", isto é, a idéia de que as diferenças entre a personalidade masculina e feminina são construções eminentemente sociais, porém ancoradas nas diferenças biológicas (Nicholson, 2000). Dito de outro modo, cada sociedade "representaria" as diferenças de gênero sobre a "base sexual". Por fim, alguns autores argumentam

que o gênero é um conhecimento/discurso que estabelece significados para as diferenças sexuais, ou seja, o gênero é o conhecimento que constitui o sexo e a diferença sexual (Costa, 2003:172).

Mesmo autores que sustentam que as diferenças de gênero resultariam de uma relação inconsciente dos seres humanos com suas respectivas constituições corporais (Chodorow, 1978) não deixam de levar em conta que as práticas sociais têm peso na constituição dos gêneros. Indubitavelmente, as mudanças significativas na condição social das mulheres, desde o final do século XIX, foram fundamentais para desnaturalizar algumas características, comportamentos e formas de pensar tidas como exclusivamente femininas. Esse processo colaborou para que se conjecturasse que as diferenças de gênero, apesar de relacionadas às de sexo, não poderiam ser reduzidas a estas últimas.

Sob esta perspectiva, merece atenção o efeito da marginalização das mulheres em relação ao Estado sobre as construções de gênero. Joan Scott (1990) ressalta o papel do Estado como arena de maior resistência à penetração das mulheres, o que foi decisivo para a permanência da identificação entre público/masculino e privado/feminino, mesmo após a saída das mulheres para o mercado de trabalho em meados do século passado. Numa perspectiva mais teórica, Elleni Varikas (2003) explora o trabalho intelectual dos mais importantes autores da filosofia política $e$, sobretudo, mapeia sua influência na 
constituição do Estado, com especial destaque para a justificação da subordinação privada e pública das mulheres por eles arquitetada. Christine Delphy (1994) adiciona a esse debate o argumento de que o insulamento das mulheres parlamentares em temas de menos prestígio social (como as soft politics) pode ser decorrente das barreiras impostas a elas no campo político. Barreiras estas ligadas tanto aos estereótipos sobre a feminilidade dos parlamentares homens, quanto às possibilidades maiores de acumulação de status político por parte daquelas que se dedicam a tais temas.

Entretanto, é inegável que a recente incorporação das representações feministas sobre a mulher e sua posição social tem grande relevância na própria reconstituição das relações de gênero $e$, ocasionalmente, um relativo impacto político. Como observa Clara Araújo (2005), o alto grau de legitimidade perante a sociedade de algumas representações sobre as relações de gênero, cultivadas no interior dos movimentos feministas, permitiu que, intuitivamente, a baixa participação das mulheres no parlamento fosse vista como, no mínimo, uma injustiça social.

Tal "intuição" cooperou para a justificação e aceitação do estabelecimento das cotas eleitorais para mulheres em muitos países e se baseou nas mais diferentes representações sociais sobre a mulher: seja como possuidora de um "olhar maternal" elementar (Chodorow, 1978; Gilligan, 1982) - posteriormente considerado fundamental para a reformulação da prática política que as democracias atualmente demandam (Ruddick, 1989; Elshtain 1981) -, seja por considerar que elas possuem perspectivas sociais diferenciadas e silenciadas historicamente pelos governos ditos representativos e por uma estrutura social excludente (Young, 2006; Phillips, 2001).

Entretanto, destacamos que a pequena parcela de representantes mulheres nos parlamentos ao redor do mundo não fere o princípio de justiça implícito no ordenamento formal das democracias liberais, logo, não é uma injustiça "obviamente" antidemocrática. Em tese, as democracias representativas se baseiam 
O Oito de Março no Congresso

no princípio utilitarista de que cada cidadão (eleitor) é o melhor juiz de seus interesses. Portanto, se as mulheres estão fora das arenas representativas, isso seria a mera expressão da vontade popular (Miguel, 2000).

\section{O desenho da pesquisa}

Para resgatar as representações sociais dos parlamentares sobre a mulher, optou-se pela análise dos discursos proferidos pelos deputados federais durante o Dia Internacional da Mulher $e$ durante as sessões solenes ocorridas em comemoração à data, de 1975 até 2006. As notas taquigráficas dos pronunciamentos foram obtidas via internet no site da Câmara dos Deputados. Elas foram lidas e analisadas mais detidamente quando o pronunciamento fazia alguma referência à mulher, ao seu dia ou a algum tema que diretamente a atingisse.

$\mathrm{O}$ fato de poucos cidadãos se interessarem pelos discursos proferidos no parlamento muitas vezes leva a crer que tais discursos estariam muito mais próximos de fúteis representações teatrais com reduzido efeito político. Contudo, apesar dessa aparente "futilidade", deputados dos mais diferentes status continuam a concorrer por alguns minutos na tribuna. Nesse sentido, é necessário indagar a importância dos pronunciamentos parlamentares como instrumentos políticos centrais $e$, por esse motivo, escolhidos como objeto de pesquisa.

A minúscula publicidade da maioria dos discursos esconde seu efeito dentro do próprio campo político como uma importante via para estabelecer compromissos com os pares e com os agentes "externos", como grupos de pressão e lobbies organizados. Por mais sem importância que possa parecer, exaltar a figura da mulher como mãe ou dedicar o tempo na tribuna à discussão da violência doméstica é marcar o território político, aproximar-se de determinados parlamentares e distanciar-se de outros, declarando uma predisposição favorável ou contrária a determinados projetos políticos. Como aponta Giumbelli (2002:96), 
Luiz Augusto Campos e Luís Felipe Miguel

\begin{abstract}
Quando se observa uma polêmica, na qual, acerca de um dado assunto, intervém uma série de agentes sociais, podese tratá-la apenas como uma convulsão efêmera, fadada a arrefecer tão logo outros assuntos ganhem o centro das atenções. De fato, é assim que se passa com a maioria das controvérsias. No entanto, sem negar sua ocorrência passageira, pode-se considerá-las como um momento de expressão e redefinição de pontos e problemas, os quais permanecem importantes, às vezes até cruciais, na constituição de uma sociedade, mesmo quando não despertam interesse generalizado ou intenso. (...) A controvérsia é uma espécie de drama social, que revela mas também reconfigura definições de realidade, explicitando o conflito que existe em torno dessas definições.
\end{abstract}

Complementarmente, a referência a determinados temas durante os pronunciamentos, ou a presença de alguns enquadramentos, constitui um importante índice do que os agentes políticos pensam da realidade, bem como daquilo que eles preferem ou podem expressar dadas as suas estratégias políticas e perante os limites impostos pelas fronteiras do dizível, dos discursos politicamente adequados ao campo num dado momento. Do mesmo modo, o corpus da pesquisa pode ser visto como um agregado das visões do que os parlamentares querem que os outros pensem, e de como gostariam que a realidade fosse interpretada, em outras palavras, de como eles tentam alterar os limites do dizível, dos discursos politicamente adequados. Nesse sentido, as discussões públicas sobre a mulher contribuem decisivamente para criar ou potencializar determinadas representações sociais sobre o que, de fato, diferencia os gêneros $e$, destarte, o que vem a ser um "gênero".

Somente os discursos da Câmara dos Deputados foram analisados, excluindo os do Senado Federal. Todos os discursos proferidos nos pequeno e grande expedientes daquela Casa Legislativa, bem como os proferidos durante as sessões solenes dedicadas ao tema foram catalogados. Algumas dessas sessões 
O Oito de Março no Congresso

foram conjuntas entre Câmara e Senado e, por isso, alguns discursos de senadores foram incluídos no universo. Porém, no decorrer do texto sempre nos referiremos a deputados $e$ deputadas federais, já que estes constituem a grande maioria dos que compõem o corpus de pesquisa.

Em cada discurso, buscou-se até duas abordagens centrais. As abordagens presentes em mais de dois discursos foram categorizadas segundo a lista a seguir:

1) Mera saudação: casos em que houve uma simples saudação à mulher, ao dia ou alguma questão relativa ao tema.

2) Exaltação da beleza/pureza/grandeza da mulher: discursos centrados na suposta superioridade moral feminina ou na sua beleza idílica.

3) Papel da mulher na família: categoria que congrega alusões ao papel da mulher na manutenção, união e reprodução da família enquanto estrutura social vital dotada de certa "nobreza". São excluídas desta classe as passagens em que se destacava o papel da mulher enquanto mantenedora puramente econômica da família ("chefe de família"). Essas referências, estão presentes na categoria papel da mulher na economia (incluindo na família), Isso permitiu perceber quando houve a associação entre mulher e a esfera puramente privada (a família) e, de modo diverso, quando ocorreu a conexão entre mulher e a participação no mundo do trabalho (público). Em alguns discursos, tal contraposição era explícita:

Hoje infelizmente, pelas vicissitudes da vida, as dificuldades em que vivemos, a mulher, em vez de estar no lar ao lado dos filhos, é obrigada, por circunstâncias, a estar no trabalho para ajudar o sustento da familia, o que, às vezes, a afasta do precioso momento de comunhão ao lado dos seus filhos, cuidando das obrigações do lar (Deputado Benedito Domingos, PPB-DF, 8/03/1996).

4) Papel da mulher na economia (incluindo na família): todas as citações que evocavam a entrada da mulher no mercado, 
a relevância desta participação e seu crescimento recente, bem como os discursos que exaltam s mulher como "chefe de família".

5) Aumento da participação política feminina: discursos que destacam o crescimento $e$ importância da participação política feminina, em sentido amplo, mas quase sempre se referindo à participação eleitoral ou à penetração nas arenas decisórias. ${ }^{5}$

6) Saúde feminina: menções às políticas sobre a saúde feminina bem como aos problemas considerados tipicamente femininos.

7) Homenagem a algum movimento ou personalidade: discursos que tinham como centro a exaltação da figura/experiência de grupos ou indivíduos vistos como especialmente importantes para as causas das mulheres.

8) História da mulher ou do feminismo: devido ao fato de uma parcela significativa dos discursos fazerem referência à história da mulher ou do feminismo esta categoria só foi escolhida quando não havia menção a qualquer outra abordagem.

9) Comentário sobre alguma política voltada para a mulher: citação de política pública ou programa governamental específico para a mulher. Esta categoria também é residual, pois só era marcada quando o discurso estava focado na configuração da política pública em questão e não havia qualquer referência ao seu papel ou importância para a mulher ou para as desigualdades de gênero.

\footnotetext{
${ }^{4}$ Estão excluídos desta categoria todos os discursos que falam das desigualdades e obstáculos impostos às mulheres no mercado e também aqueles que falam sobre dupla jornada de trabalho. Estes foram incluídos na categoria desigualdades no mercado de trabalho. Com isso, foi possível captar não somente orientações temáticas, mas também se o discurso estava centrado numa avaliação apologética ou crítica da participação da mulher no mercado.

${ }^{5}$ Demandas por participação em arenas decisórias representativas (ou consideradas como tal) foram excluídas dessa categoria e agrupadas em demanda por representação política feminina.
} 
O Oito de Março no Congresso

10) Desigualdade de direitos civis: qualquer referência a alguma desigualdade entre homens e mulheres sustentada ou decorrente de leis ou princípios legais específicos.

11) Violência contra a mulher: qualquer tipo de violência contra a mulher, incluindo a violência moral, estupro, agressão física etc. Outro grupo incluído aqui se refere às menções à prostituição quando relacionadas à idéia de violência contra o arbítrio feminino.

12) Direitos reprodutivos: discursos que falavam sobre o direito ao aborto e, excepcionalmente, sobre o uso de anticoncepcionais, desde que o enquadramento privilegiasse a reprodução feminina e não a saúde feminina ou a saúde pública.

13) Desigualdades no mercado de trabalho: menções às desigualdades salariais, hierárquicas e de cargos entre homens $e$ mulheres assim como à dupla jornada. Como ressaltado, discursos apologéticos sobre a participação das mulheres no mercado eram categorizados como papel da mulher na economia.

14) Demanda por representação feminina no poder: qualquer reivindicação de aumento da presença de mulheres em esferas decisórias, ou quando se enfocava a diminuta quantidade delas nestas arenas. Não somente a demanda por mais mulheres no parlamento foi incluída, mas também defesas do aumento de mulheres na justiça, nos cargos públicos, na chefia de ministérios etc. desde que se apelasse de alguma maneira à necessidade de que tais arenas fossem "representativas". A diferença entre esta categoria em relação à categoria 5 (aumento da participação política feminina) é, sobretudo, de enquadramento ou direcionamento: quando o discurso exaltava o aumento da participação política feminina, era encaixado em 5 , quando reivindicava a maior presença de mulheres na política, era encaixado aqui. A seguir, um exemplo de discurso que, apesar de falar da mulher nas arenas decisórias, assumiu um tom apologético e, por isso, foi encaixado na abordagem 5 : 
Luiz Augusto Campos e Luís Felipe Miguel

Quando, em 1934, Bertha Lutz disputava sem êxito, uma cadeira no Senado brasileiro, ninguém esperava que vinte anos depois a Professora baiana Nita Costa conquistasse o mandato de Deputada Federal, o que abriu o caminho de nada mais que cinco mulheres, neste Plenário, na quinta Legislatura depois de 1946 (Deputado Francisco Libardone, MDB-PR, 8/3/1978, ênfase acrescentada).

15) Preconceito, sexismo, machismo, patriarcalismo: discurso sobre preconceitos que diminuem as mulheres ou se constituem na causa de sua marginalidade social.

16) Desigualdades de gênero (genérico): discursos centrados nas desigualdades de gênero apresentadas de forma geral, sem especificações.

Diante da grande quantidade de abordagens, em algumas partes da análise optou-se por agrupá-las de acordo com objetivos específicos. Para entender o direcionamento dado por homens e mulheres aos discursos foram forjadas três categorias-resumo, o que possibilitou ressaltar não somente as abordagens, mas alguns enquadramentos, apologéticos, "neutros" ou críticos, respectivamente. 
O Oito de Março no Congresso

Quadro 1 - Abordagens agrupadas de acordo com o enquadramento

\begin{tabular}{|c|c|c|}
\hline \multirow{5}{*}{$\begin{array}{l}\text { Elogios, } \\
\text { saudações e/ou } \\
\text { exaltação da } \\
\text { mulher e de seu } \\
\text { papel na } \\
\text { sociedade }\end{array}$} & 1 & mera saudação \\
\hline & 2 & $\begin{array}{l}\text { exaltação da } \\
\text { beleza/pureza/grandeza da mulher }\end{array}$ \\
\hline & 3 & papel da mulher na família \\
\hline & 4 & $\begin{array}{l}\text { papel da mulher na economia } \\
\text { (incluindo na família) }\end{array}$ \\
\hline & 5 & $\begin{array}{l}\text { aumento da participação política } \\
\text { feminina }\end{array}$ \\
\hline \multirow{4}{*}{$\begin{array}{l}\text { Comentários } \\
\text { sobre o } \\
\text { feminismo, } \\
\text { história da } \\
\text { mulher ou } \\
\text { política pública }\end{array}$} & 6 & saúde feminina \\
\hline & 7 & $\begin{array}{l}\text { homenagem a algum movimento } \\
\text { ou personalidade }\end{array}$ \\
\hline & 8 & $\begin{array}{l}\text { história da mulher ou do } \\
\text { feminismo }\end{array}$ \\
\hline & 9 & $\begin{array}{l}\text { comentário sobre alguma política } \\
\text { para a mulher }\end{array}$ \\
\hline \multirow{7}{*}{$\begin{array}{l}\text { Críticas, } \\
\text { reivindicações, } \\
\text { denúncias } \\
\text { relacionadas à } \\
\text { mulher }\end{array}$} & 10 & desigualdade de direitos civis \\
\hline & 11 & violência contra a mulher \\
\hline & 12 & direitos reprodutivos \\
\hline & 13 & $\begin{array}{l}\text { desigualdade no mercado de } \\
\text { trabalho }\end{array}$ \\
\hline & 14 & $\begin{array}{l}\text { demanda por representação } \\
\text { feminina no poder }\end{array}$ \\
\hline & 15 & $\begin{array}{l}\text { preconceito, sexismo, machismo, } \\
\text { patriarcalismo }\end{array}$ \\
\hline & 16 & $\begin{array}{l}\text { desigualdades de gênero } \\
\text { (genérico) }\end{array}$ \\
\hline
\end{tabular}

Outro objetivo da pesquisa foi entender a importância do Dia Internacional da Mulher para os parlamentares. A representação sobre a "função" desta data diz muito sobre o estágio da situação da mulher na concepção de quem discursa. A quase totalidade dos discursos com alguma referência sobre a importância do 8 de Março foi abrigada em cinco as categorias básicas, indicadas no quadro 2. A questão permitia até duas respostas e, eventualmente, as cinco categorias foram agregadas seguindo o critério de que existem representações que subliminarmente realçam o cenário de fortes desigualdades, enquanto outras enfatizam os motivos para comemorar $e$ as vitórias conquistadas. 
Luiz Augusto Campos e Luís Felipe Miguel

Quadro 2: Relevância do Dia Internacional da Mulher agrupada de acordo com enquadramento

\begin{tabular}{|l|c|l|}
\hline $\begin{array}{l}\text { Dia da mulher } \\
\text { como data de } \\
\text { comemoração }\end{array}$ & 1 & homenagear à grandeza feminina \\
\cline { 2 - 3 } & 2 & $\begin{array}{l}\text { comemorar as conquistas históricas da } \\
\text { mulher }\end{array}$ \\
\hline \multirow{2}{*}{$\begin{array}{l}\text { Dia da mulher como } \\
\text { data de reflexão }\end{array}$} & 3 & $\begin{array}{l}\text { reforçar a busca pela igualdade entre } \\
\text { gêneros }\end{array}$ \\
\cline { 2 - 3 } & 4 & lamentar momentos tristes do feminismo \\
\cline { 2 - 3 } & 5 & $\begin{array}{l}\text { lembrar as desigualdades ainda } \\
\text { existentes }\end{array}$ \\
\hline
\end{tabular}

Grande parcela dos discursos também continha, explícita ou implicitamente, alguma imagem clichê da mulher. Portanto, quando possível, inferiu-se a representação de mulher dominante no discurso, categorizadas em cinco tipos, indicados no quadro 3. Também nessa questão até duas opções podiam ser escolhidas para cada discurso.

Quadro 3 - Estereótipos agrupados de acordo com enquadramento

\begin{tabular}{|l|c|l|}
\hline Estereótipos & 1 & mãe ou cuidadora \\
Conservadores & 2 & companheira \\
& 3 & pura, sensível, boa \\
\hline Estereótipos & 4 & guerreira e lutadora \\
"Militantes" & 5 & vítima social \\
\hline
\end{tabular}

O discurso do deputado Avenir Rosa é exemplar em relação ao primeiro bloco de estereótipos:

Quero mostrar, na minha fala, quatro faces, quatro imagens que se fundem numa só pessoa, tornando-a, ao mesmo tempo, única e múltipla. Em primeiro lugar, a imagem de companheira. Após criar o homem, disse Deus: "Não é bom que o homem esteja só". A mulher nasce, segundo a narrativa bíblica, para povoar a solidão do homem. A mulher nasce para ser companheira. (...) A segunda imagem que ponho em tela é a imagem da mulher como Mãe. Muito já se falou, ao longo da história, a respeito 
O Oito de Março no Congresso

dessa mais sublime dimensão da mulher. Qualquer coisa que se acrescente será sempre redundância. Instrumento primeiro a completar a obra da criação, a mulher é, ao mesmo tempo, terra e semente, princípio biológico de toda vida humana. (...) Sua visão de mundo, sua sensibilidade, sua extraordinária intuição conseguem penetrar onde a objetividade fria do homem se anula e se perde (Deputado Avenir Rosa, PDC-RR, 8/3/1991).

A deputada Almerinda de Carvalho ilustra bem o segundo bloco de estereótipos:

No Dia Internacional da Mulher, parabenizo as mulheres brasileiras, mulheres guerreiras, as mulheres do Estado do Rio de Janeiro, as mulheres funcionárias desta Casa, que têm sido grandes participantes no processo legislativo da Câmara dos Deputados. Nós mulheres não podemos desistir nunca. Precisamos nos unir cada vez mais para mostrar nossa competência e nosso valor. Sr. Presidente, Sras. e Srs. Deputados, em que pese o reconhecimento do papel da mulher na vida e em todos os ramos de atividade, entendo que ainda há pouco que se comemorar, pois é marcante a discriminação, a violência e os preconceitos que predominam em relação à mulher (Deputada Almerinda de Carvalho, PMDB-RJ, 8/3/2005).

\section{Quem, quando e como falam da mulher}

Dos 893 discursos incluídos no recorte de pesquisa, 14,3\% foram proferidos por deputadas. Apesar de pequeno, este percentual é maior do que o de deputadas que passaram pela Câmara na última legislatura $(9 \%)$ e quase o triplo da proporção de deputadas que passaram pela Casa no período analisado. ${ }^{6}$ Isso indica que, nas sessões de homenagem ao 8 de março, o espaço

${ }^{6}$ Isso inclui deputadas e deputados titulares ou suplentes que passaram pela Câmara e não somente aqueles eleitos ou empossados no início da legislatura. 
conferido à mulher é significativamente maior do que sua representatividade no parlamento. Indica, também, que nestas sessões elas têm mais oportunidade de ocupar a tribuna do que nas outras, posto que o percentual de discursos proferidos por mulheres nas últimas duas legislaturas foi de 6,7\% (Miguel et alii, 2006).

A quantidade de discursos que trata, mesmo que superficialmente, dos temas relacionados à mulher, nas sessões analisadas, beira os $50 \%$. Quase todas as mulheres que nelas discursaram fizeram alguma referência às temáticas relacionadas a gênero, enquanto três quintos dos homens não fizeram qualquer menção, como indica a tabela 1.

Tabela 1: Pertinência dos discursos às questões de gênero de acordo com o sexo do parlamentar

\begin{tabular}{lcc}
\hline & feminino & masculino \\
\hline $\operatorname{sim}$ & $92,2 \%(118)$ & $39,5 \%(302)$ \\
\hline não & $7,8 \%(10)$ & $60,5 \%(463)$ \\
\hline Total & $\mathbf{4 7 , 0 \% ( 1 2 8 )}$ & $\mathbf{5 3 , 0 \% ( 7 6 5 )}$
\end{tabular}

Fonte: compilação dos autores.

A tabela 2 mostra outra importante clivagem relativa às questões de gênero. Nela fica patente que os membros de partidos considerados de esquerda ${ }^{7}$ fazem muito mais discursos sobre o tema do que os partidos considerados de centro ou de direita, sendo que estas duas últimas "cores" partidárias possuem diferenças leves. Contudo, deve-se destacar que a maioria das

7 A divisão dos partidos em "direita", "centro" e "esquerda" seguiu o padrão corrente na ciência política brasileira. Para o período bipartidário, a ARENA foi considerada de direita e o MDB, em que pese sua heterogeneidade, de centro. No período multipartidário, foram classificados como "direita": PDS, PFL, PTB, PP, PL, PPR, PPB, PDC, PRN, PSC, PTR, PRB, PR, PSD, PST e PRONA "centro": PMDB e PSDB; "esquerda": PT, PDT, PSB, PPS, PCB, PCdoB, PSOL, $\mathrm{PV}$ e PMN. 
O Oito de Março no Congresso

mulheres que passaram pela Câmara foi eleita por partidos de esquerda, o que pode ter levado à maior quantidade de discursos sobre a mulher proferidos. Das 144 mulheres que passaram pela Câmara Federal de 1975 até 2007, 59 (40,9\%) eram ligadas a algum partido considerado pela pesquisa como de esquerda. A tabela 2 ainda mostra a proximidade dos números dos partidos de direita e de centro.

Tabela 2 - Pertinência dos discursos às questões de gênero de acordo com a posição partidária do parlamentar

\begin{tabular}{lccc}
\hline & sim & não & Total \\
\hline \multirow{2}{*}{ direita } & $40,8 \%$ & $59,2 \%$ & $\mathbf{1 0 0 \%}$ \\
& $(137)$ & $(199)$ & $\mathbf{( 3 3 6 )}$ \\
\multirow{2}{*}{ centro } & $39,2 \%$ & $60,8 \%$ & $\mathbf{1 0 0 \%}$ \\
& $(129)$ & $(200)$ & $\mathbf{( 3 2 9 )}$ \\
\multirow{2}{*}{ esquerda } & $67,6 \%$ & $32,4 \%$ & $\mathbf{1 0 0 \%}$ \\
& $(152)$ & $(73)$ & $\mathbf{( 2 2 5 )}$ \\
\multirow{2}{*}{ Total } & $\mathbf{4 7 , 0 \%}$ & $\mathbf{5 3 \%}$ & $\mathbf{1 0 0 \%}$ \\
& $\mathbf{( 4 1 8 )}$ & $\mathbf{( 4 7 2 )}$ & $\mathbf{( 8 9 0 )}$
\end{tabular}

Fonte: compilação dos autores (foram excluídos da tabela três discursos proferidos por parlamentares "sem partido" no período).

No entanto, não se pode afirmar que a maior quantidade de discursos sobre o tema nos partidos de esquerda se deva exclusivamente à maior parcela de mulheres em seu interior. Como mostra a tabela 3 , deputados homens dos partidos de esquerda também falam muito mais sobre o tema se comparados a seus pares de centro ou de direita. Reiteramos a grande proximidade entre estas últimas duas tendências políticas. 
Luiz Augusto Campos e Luís Felipe Miguel

Tabela 3 - Pertinência dos discursos às questões de gênero proferidos somente por homens de acordo com a posição partidária do parlamentar

\begin{tabular}{lccc}
\hline & sim & não & Total \\
\hline \multirow{2}{*}{ direita } & $34,7 \%$ & $65,3 \%$ & $\mathbf{1 0 0 \%}$ \\
& $(104)$ & $(196)$ & $\mathbf{( 3 0 0 )}$ \\
\hline \multirow{2}{*}{ centro } & $31,5 \%$ & $68,5 \%$ & $\mathbf{1 0 0 \%}$ \\
& $(91)$ & $(198)$ & $(\mathbf{2 8 9 )}$ \\
\hline \multirow{2}{*}{ esquerda } & $60,9 \%$ & $39,1 \%$ & $\mathbf{1 0 0 \%}$ \\
& $(106)$ & $(68)$ & $\mathbf{( 1 7 4 )}$ \\
\hline \multirow{2}{*}{ Total } & $\mathbf{3 9 , 4 \%}$ & $\mathbf{6 0 , 6 \%}$ & $\mathbf{1 0 0 \%}$ \\
\multirow{2}{*}{ Fonte: } & $\mathbf{( 3 0 1 )}$ & $\mathbf{( 4 6 2 )}$ & $\mathbf{( 7 6 3 )}$
\end{tabular}

proferidos por parlamentares homens "sem partido" no período).

O gráfico 1 mostra a proporção de discursos que mencionaram o assunto em cada legislatura, de 1975 até 2006. Como fica patente, a parcela de discursos que tratou do tema foi quase nula na $45^{\circ}$ legislatura (1975-1978), crescendo substantivamente até a 50 a legislatura (1995-1998), quando se estabiliza.

Gráfico 1: Quantidade relativa de discursos sobre as questões de gênero proferidos no 8 de março, da $45^{\mathrm{a}}$ à $52^{\mathrm{a}}$ legislatura

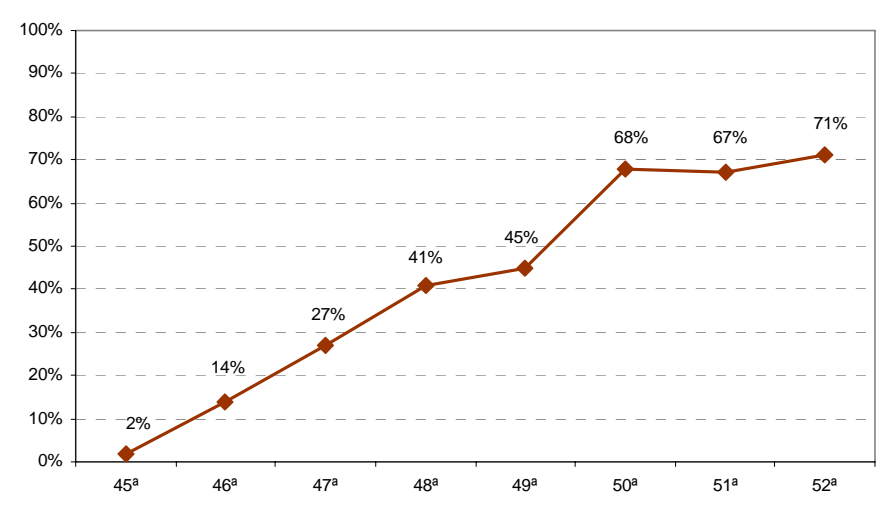

Fonte: os autores 
O Oito de Março no Congresso

Embora de forma tímida e não-linear, o número de mulheres na Câmara dos Deputados aumentou ao longo do período estudado. $\mathrm{Na} 45^{\mathrm{a}}$ legislatura, não houve nenhuma deputada; na 52a (2003-2006), elas foram $9 \%$ do total. Não existe uma correlação significativa entre o percentual de mulheres que passaram pelo parlamento e o percentual de discursos proferidos por mulheres $(\mathrm{r}=0,582)$ ou o mesmo entre o percentual de mulheres que passaram pelo parlamento e o percentual daquelas que se manifestaram sobre o tema $(\mathrm{r}=-0,306)$. Contudo, foi identificada uma alta correlação entre o percentual de mulheres na Câmara e o percentual de discursos sobre o tema proferidos por deputados e deputadas $(\mathrm{r}=0,961)$. Dito de outro modo, à medida que a quantidade relativa de mulheres no parlamento cresceu, aumentou proporcionalmente o espaço dedicado a elas nos discursos. Mas não aumentou em proporção significativa a quantidade de discursos dedicados ao tema proferidos pelas próprias mulheres. Isto é, não se pode afirmar que o aumento do número de mulheres na Câmara dos Deputados tenha sido uma causa do incremento da quantidade relativa de discursos sobre o tema, posto que aquele aumento não foi seguido de uma elevação dos discursos proferidos sobre o tema por mulheres. Pode-se sim conjecturar que houve o crescimento de um "feminismo difuso" (Pinto, 2003), que tanto levou à Câmara mais mulheres como propiciou uma maior atenção ao tema.

Do total de discursos que falam sobre as questões de gênero, $68,6 \%$ dedicam um espaço central a elas, $12,4 \%$ um espaço secundário e $19 \%$ apenas as mencionam. Merece reflexão o fato das mulheres tratarem com muito mais centralidade tais temas do que os homens $-85,6 \%$ dos discursos pronunciados por mulheres tratam das questões de gênero de forma central, enquanto os homens o fazem em $61,9 \%$ dos casos. Além disso, eles "apenas mencionam" tais assuntos em $24,5 \%$ dos discursos que tratam das questões de gênero, enquanto o mesmo percentual para as mulheres é de $5,1 \%$. 
A partir de certo momento, a menção às questões levantadas por ocasião ao dia da mulher se tornou obrigatória para alguns deputados. Uma prática comum foi "casar" temas diversos com as questões de gênero, utilizadas mais como pretexto. Apesar da pesquisa não ter objetivado verificar a quantidade destes discursos, é importante ressaltar a ocorrência desta prática:

Mas há lugares em que a presença da mulher é tão vital que, sem ela, não seria possível imaginar um processo de ocupação humana, de implantação da civilização, de desenvolvimento econômico e até de alargamento das fronteiras nacionais. É o caso do Amapá, meu Estado. O Amapá é tão distante dos centros de decisão do Poder Nacional que não é incomum encontrar-se autoridades de alto coturno que sequer sabem, exatamente, onde fica aquele importante e rico pedaço do Brasil (Deputado Dr. Benedito Dias, do PPB-AP, em 8 de março de 2001).

Sr. Presidente, Srs. Parlamentares, quero, inicialmente, no transcurso do Dia Internacional a Mulher, dedicar o meu pronunciamento às trabalhadoras rurais, às mulheres do campo, que, a despeito de serem as mulheres que mais trabalham - $e$ trabalham mais que os próprios homens sentem os principais problemas $e$ as maiores dificuldades. (...) Sr. Presidente, não poderia, no momento em que a agricultura vive o seu pior momento, num espaço de 25 minutos, deixar de abordar o problema da agricultura e da agropecuária do nosso País (Deputado Luiz Mainardi, do PRRS, em 8 de março de 1997).

Nos dois trechos, considerações sobre a condição feminina foram bruscamente abandonadas em favor de temas relativamente distantes do assunto inicial. Nestes casos, o discurso transcorreu sem qualquer retorno ao tema, o que demonstra uma relativa obrigatoriedade de se tratar do assunto, mesmo que ele não seja considerado o mais importante naquele contexto. 
O Oito de Março no Congresso

\section{O que falam da mulher}

No tópico anterior, delinearam-se alguns "perfis" dos parlamentares em relação às questões de gênero, bem como o espaço que as questões de gênero ocupam nos discursos. Esta parte, por seu turno, estará focada menos na forma do discurso $e$ mais em seu conteúdo semântico. O gráfico 2 aponta as quantidades relativas das abordagens relativas às questões de gênero, em ordem decrescente de ocorrências.

Gráfico 2: Quantidade relativa de presença de cada abordagem

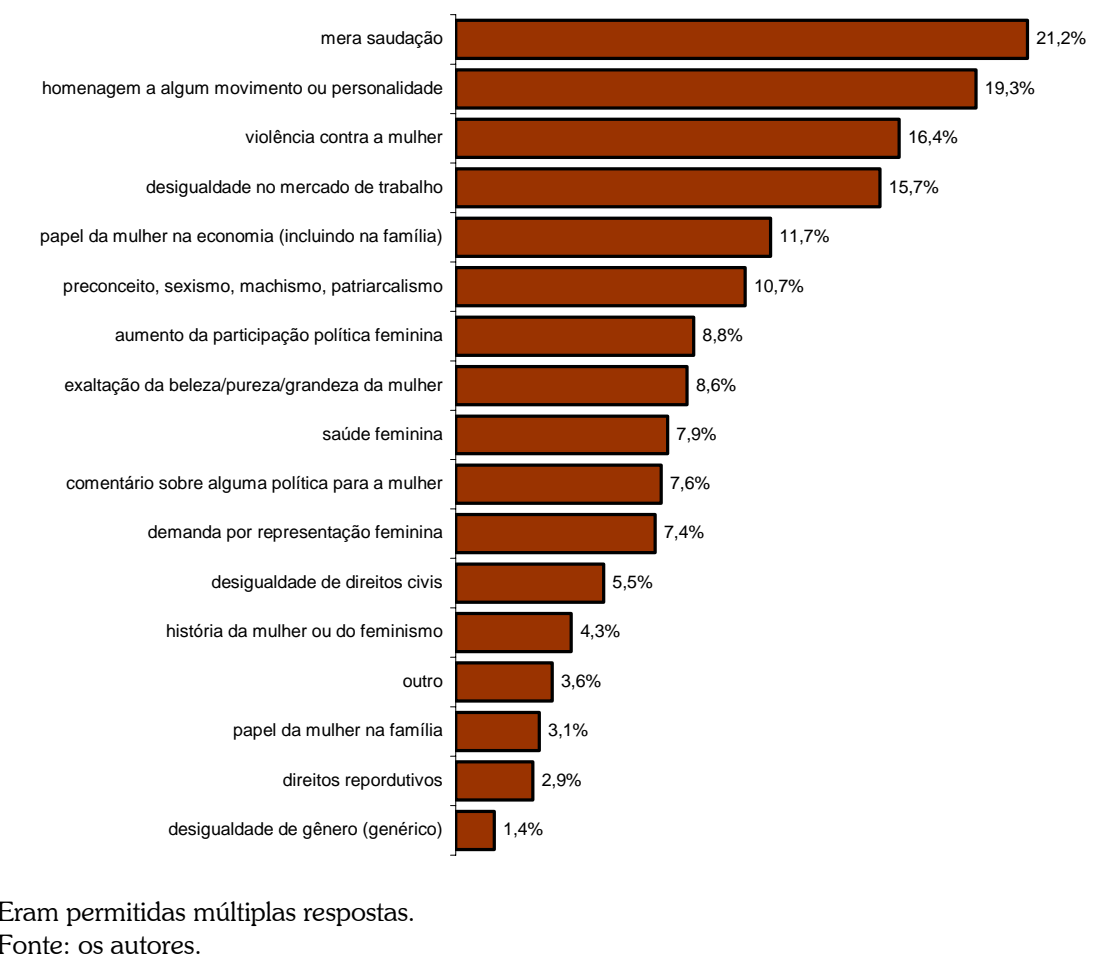


Os números reafirmam a percepção de que a menção ao tema, ainda que de forma apenas protocolar, tornou-se uma quase obrigação - $e$ não só nas sessões solenes. Talvez por isso grande quantidade relativa de pronunciamentos (21,2\%) faça referência à mulher apenas com "mera saudação", isto é, uma breve lembrança à data ou um rápido cumprimento. Das 89 "meras saudações", 83 são de parlamentares homens. Em segundo lugar, destacam-se os discursos em homenagem a alguma personalidade ou movimento social específico. Em todos os casos, as personalidades homenageadas são mulheres, porém das mais diferentes posições sociais, com destaque para políticas ou líderes de movimentos sociais (23,3\% e 12,6\% respectivamente). Movimentos sociais em si foram lembrados também em 12,6\% citações. Curiosamente, em quarto lugar, com 9,7\% das citações, estão mulheres consideradas de destaque por possuírem "laços familiares" com o discursando ou com alguma personalidade outra categoria mais freqüente entre os homens (foi assinalada em $14,4 \%$ dos discursos deles) do que entre as mulheres (presente em $8,4 \%$ dos discursos delas). Entram aqui homenagens à mãe, esposa, filha etc. do orador, bem como a familiares de personalidades políticas, sobretudo primeiras-damas. Apesar desses estereótipos serem objetos de análise posteriormente, cabe, desde já, realçar a exaltação da figura da mulher companheira $e$ mãe:

Sr. Presidente, gosto tanto de mulher que dos meus 12 filhos 8 são mulheres. Homenageio particularmente minha filha mais velha e minha caburezinha Juliana, que me ouve dizer que as mulheres brasileiras vão fazer a revolução do mundo (Deputado Gonzaga Patriota, PSB-PE, 8/3/2006).

Por último, Senhoras Deputadas e Senhores Deputados, quero prestar homenagem toda especial à mulher dos meus sonhos, àquela que foi a esposa ideal, a mãe dos meus filhos, a companheira inseparável de minha vida: Geralda Medeiros (Deputado Rivaldo Medeiros, PRN-PB, 8/3/1994). 
O Oito de Março no Congresso

As divergências entre os discursos de homens e os de mulheres pode ser observada no gráfico 3. Ele apresenta a diferença, em pontos percentuais, entre a presença de cada abordagem entre os pronunciamentos dos deputados $e$ das deputadas. Exemplificando, dentre os discursos proferidos por homens, as "meras saudações" foram 27,48\%. Já dentre as mulheres, ficaram em apenas $5,08 \%$. A diferença entre os dois percentuais $(22,4$ pontos) indica que os homens preferem muito mais este tipo de discurso do que as mulheres. No topo estão as abordagens prediletas dos homens e na base, as das mulheres.

Gráfico 3: Abordagens prediletas de acordo com o sexo do parlamentar

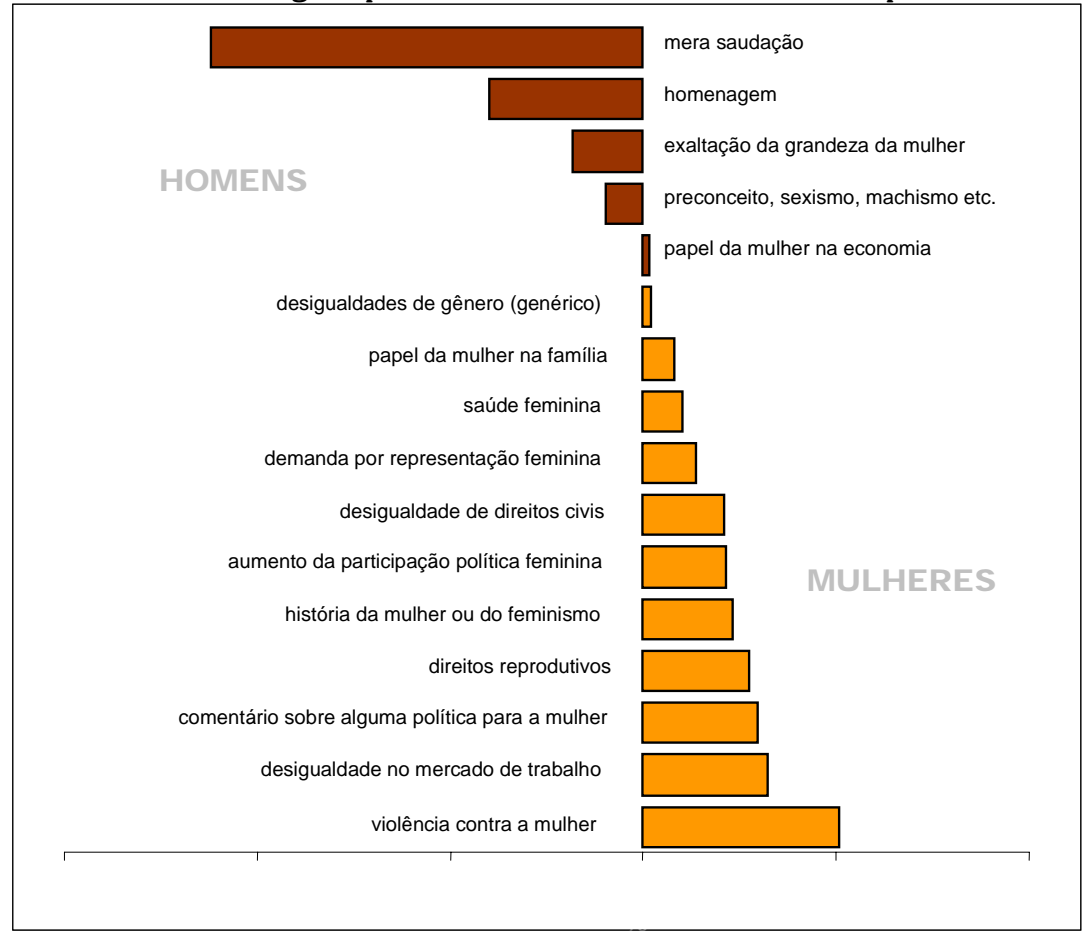

Eram permitidas múltiplas respostas. As barras indicam a diferença, em pontos percentuais, da presença da abordagem nos discursos de parlamentares homens e de parlamentares mulheres. Fonte: compilação dos autores. 
A tabela 4, abaixo, agrupa as 16 categorias nos três grandes grupos, conforme indicado no quadro 1 , demonstrando a diferença nas abordagens de homens e mulheres.

Tabela 4: Presença relativa de grupos de abordagens nos discursos de acordo com o sexo do parlamentar

\begin{tabular}{lccc}
\multicolumn{4}{c}{ fe acordo com o sexo do parlamentar } \\
\hline $\begin{array}{l}\text { Elogios, saudações } \\
\text { e/ou exaltação da }\end{array}$ & $42,2 \%$ & masculino & Total \\
$\begin{array}{l}\text { mulher e de seu } \\
\text { papel na sociedade }\end{array}$ & $(46)$ & $60,1 \%$ & $\mathbf{5 5 , 3 \%}$ \\
\hline $\begin{array}{l}\text { Comentários sobre } \\
\text { o feminismo, }\end{array}$ & $45,9 \%$ & $38,5 \%$ & $\mathbf{( 2 2 4 )}$ \\
história da mulher & $(50)$ & $(114)$ & $\mathbf{4 0 , 5 \%}$ \\
ou política pública & & & $\mathbf{( 1 6 4 )}$ \\
\hline
\end{tabular}

\section{Críticas,}

reivindicações,

denúncias

relacionadas à

$86,2 \% \quad 53,4 \%$

$62,2 \%$

mulher

\begin{tabular}{lrll}
\hline Total & $\mathbf{1 0 0 \%}$ & $\mathbf{1 0 0 \%}$ & $\mathbf{1 0 0 \%}$ \\
Eram permitidas múltiplas respostas) & $\mathbf{( 2 9 6 )}$ & $\mathbf{( 4 0 5 )}$
\end{tabular}

Eram permitidas múltiplas respostas.

Foi suprimida a categoria "outras abordagens", com quinze ocorrências.

Fonte: compilação dos autores.

Estes números reforçam as conclusões expostas anteriormente: existe uma diferença de enquadramento fundamental entre deputados e deputadas, posto que elas citam muito mais abordagens vinculadas a críticas e denúncias, e aqueles ficam mais presos a discursos apologéticos.

Além das mulheres se vincularem mais às abordagens passíveis de serem denominadas como "feministas", dado seu caráter crítico, as clivagens ideológico-partidárias também influenciam. Na tabela 5, fica nítido que os partidos de esquerda dão maior realce às críticas, reivindicações e denúncias enquanto os parlamentares dos partidos de direita enfatizam em seus pronunciamentos elogios e saudações à mulher e ao seu dia. 
O Oito de Março no Congresso

Tabela 5: Presença relativa de abordagens nos discursos de acordo com a posição partidária do parlamentar

\begin{tabular}{|c|c|c|c|c|}
\hline & direita & centro & esquerda & Total \\
\hline $\begin{array}{l}\text { Elogios, saudações e/ou } \\
\text { exaltação da mulher e } \\
\text { de seu papel na } \\
\text { sociedade }\end{array}$ & $\begin{array}{c}67,2 \% \\
(90)\end{array}$ & $\begin{array}{c}64,8 \% \\
(81)\end{array}$ & $\begin{array}{c}35,4 \% \\
(51)\end{array}$ & $\begin{array}{r}54,8 \% \\
(222)\end{array}$ \\
\hline $\begin{array}{l}\text { Comentários sobre o } \\
\text { feminismo, história da } \\
\text { mulher ou política } \\
\text { pública }\end{array}$ & $\begin{array}{c}30,6 \% \\
(41)\end{array}$ & $\begin{array}{c}36 \% \\
(45)\end{array}$ & $\begin{array}{c}53,5 \% \\
(77)\end{array}$ & $\begin{array}{c}40,2 \% \\
(163)\end{array}$ \\
\hline $\begin{array}{l}\text { Críticas, reivindicações, } \\
\text { denúncias relacionadas } \\
\text { à mulher }\end{array}$ & $\begin{array}{c}54,5 \% \\
(73)\end{array}$ & $\begin{array}{c}62,4 \% \\
(78)\end{array}$ & $\begin{array}{c}69,4 \% \\
(100)\end{array}$ & $\begin{array}{c}62 \% \\
(251)\end{array}$ \\
\hline Total & $\begin{array}{l}100 \% \\
(134)\end{array}$ & $\begin{array}{l}100 \% \\
(125)\end{array}$ & $\begin{array}{l}100 \% \\
(144)\end{array}$ & $\begin{array}{l}100 \% \\
(405)\end{array}$ \\
\hline
\end{tabular}

Eram permitidas múltiplas respostas.

Foram excluídos desta tabela dois discursos proferidos por parlamentares "sem partido" no período e a categoria "outras abordagens", com quinze ocorrências.

Fonte: os autores.

A tabela 6 expõe, por seu turno, que os discursos em que a questão da mulher é tratada de forma central estão concentrados na categoria críticas, reivindicações, denúncias relacionadas à mulher. Inversamente, a maioria dos discursos em que o tema é somente mencionado se concentra na categoria oposta (elogios, saudações e/ou exaltação da mulher e de seu papel na sociedade). Isso permite inferir que a percepção de que ainda persistem desigualdades de gênero importantes faz com que o parlamentar confira maior espaço a abordagens ligadas a esta interpretação em seu discurso. Ao contrário, a idéia de que muito já se conquistou esvazia os discursos sobre o tema, sem, contudo, influir na presença das menções à mulher. 
Luiz Augusto Campos e Luís Felipe Miguel

Tabela 6: Centralidade dada a cada grupo de abordagens

\begin{tabular}{|c|c|c|c|c|}
\hline & centrais & secundárias & mencionadas & Total \\
\hline $\begin{array}{l}\text { Elogios, saudações } \\
\text { e/ou exaltação da } \\
\text { mulher e de seu } \\
\text { papel na } \\
\text { sociedade }\end{array}$ & $\begin{array}{c}46,4 \% \\
(129)\end{array}$ & $\begin{array}{c}55,3 \% \\
(26)\end{array}$ & $\begin{array}{c}86,2 \% \\
(69)\end{array}$ & $\begin{array}{r}55,3 \% \\
(224)\end{array}$ \\
\hline $\begin{array}{l}\text { Comentários sobre } \\
\text { o feminismo, } \\
\text { história da mulher } \\
\text { ou política pública }\end{array}$ & $\begin{array}{c}44,6 \% \\
(124)\end{array}$ & $\begin{array}{c}44,7 \% \\
(21)\end{array}$ & $\begin{array}{c}23,7 \% \\
(19)\end{array}$ & $\begin{array}{r}40,5 \% \\
(164)\end{array}$ \\
\hline $\begin{array}{l}\text { Críticas, } \\
\text { reivindicações, } \\
\text { denúncias } \\
\text { relacionadas à } \\
\text { mulher }\end{array}$ & $\begin{array}{c}78,8 \% \\
(219)\end{array}$ & $\begin{array}{c}46,8 \% \\
(22)\end{array}$ & $\begin{array}{c}13,7 \% \\
(11)\end{array}$ & $\begin{array}{r}62,2 \% \\
(252)\end{array}$ \\
\hline Total & $\begin{array}{l}100 \% \\
(278)\end{array}$ & $\begin{array}{c}100 \% \\
(47)\end{array}$ & $\begin{array}{c}100 \% \\
(80)\end{array}$ & $\begin{array}{l}100 \% \\
(405)\end{array}$ \\
\hline
\end{tabular}

Eram permitidas múltiplas respostas.

Foi suprimida a categoria "outras abordagens", com quinze ocorrências.

Fonte: os autores.

\section{De que mulher falam e porque falam}

Em diferentes medidas, os enfoques e direcionamentos dos pronunciamentos são condicionados pela representação de mulher partilhada por quem discursa. De modo semelhante, a concepção sobre em qual estágio se encontraria a "luta pela igualdade", também tem forte impacto na abordagem do tema $e$ na ação política dos parlamentares. Portanto, entender o estereótipo de mulher predominante nos discursos bem como recuperar as imagens sobre a luta das mulheres e pelas mulheres foi um dos objetivos do presente trabalho.

Porém, isso só foi possível quando implícita ou explicitamente era possível detectar algum vestígio no discurso que denunciasse estas duas representações. Por esse motivo, sempre foram levantadas algumas evidências dos estereótipos dominantes 
O Oito de Março no Congresso

ou das concepções sobre as lutas das mulheres. No caso da representação de mulher dominante nos discursos, apenas a menção explícita a estereótipos ou a características típicas destes autorizava a escolha de uma categoria.

Seguindo este critério, dentre os discursos que falavam das questões de gênero, mais da metade não citava nenhum estereótipo de mulher (51,9\%). Contudo, há que se lembrar que isto era menos decorrência da preferência por não mencionar visões de mulher do que o resultado da opção por simplesmente não falar do tema em si. Na maioria dos discursos em que as questões relativas à mulher eram brevemente mencionadas, praticamente não havia texto suficiente para que pudessem ser localizados indícios que permitissem deduzir estereótipos implícitos. Mas nos discursos que conferem importância central às questões de gênero, 63,1\% citam algum estereótipo.

A tabela 7 nos permite comparar os estereótipos de acordo com o sexo dos oradores. Percebe-se aí que a representação da mulher como guerreira e lutadora é mais freqüente entre as parlamentares do que entre os parlamentares. De maneira inversa, a visão da mulher como companheira mereceu pouco mais que o dobro de ocorrências nos discursos de deputados do que naqueles proferidos por deputadas. Em todas as outras categorias, há alguma diferença importante, porém não conclusiva. A mulher como vítima social também aparece mais em pronunciamentos de mulheres, enquanto as representações da mulher mãe $e$ cuidadora, bem como o de mulher pura, sensivel e boa são mais presentes entre os homens. 
Luiz Augusto Campos e Luís Felipe Miguel

Tabela 7: Estereótipos presentes nos discursos de acordo com o

\begin{tabular}{lccc}
\multicolumn{4}{c}{ sexo do parlamentar } \\
\hline \multirow{2}{*}{ guerreira e lutadora } & feminino & masculino & Total \\
& $53,7 \%$ & $39,2 \%$ & $\mathbf{4 3 \%}$ \\
\multirow{2}{*}{ vítima social } & $(29)$ & $(58)$ & $\mathbf{( 8 7 )}$ \\
& $24 \%$ & $18,2 \%$ & $\mathbf{1 9 , 8 \%}$ \\
\multirow{2}{*}{ mãe ou cuidadora } & $(13)$ & $(27)$ & $\mathbf{( 4 0 )}$ \\
& $24 \%$ & $35,8 \%$ & $\mathbf{3 2 , 7 \%}$ \\
\multirow{2}{*}{ companheira } & $(13)$ & $(53)$ & $\mathbf{( 6 6 )}$ \\
\hline \multirow{2}{*}{ pura, sensível, boa } & $11,1 \%$ & $23,6 \%$ & $\mathbf{2 0 , 3 \%}$ \\
& $(6)$ & $(35)$ & $\mathbf{( 4 1 )}$ \\
\hline \multirow{2}{*}{ Total } & $11,1 \%$ & $16,2 \%$ & $\mathbf{1 4 , 8 \%}$ \\
& $(6)$ & $(24)$ & $\mathbf{( 3 0 )}$ \\
\hline
\end{tabular}

Eram permitidas múltiplas respostas

Fonte: compilação dos autores.

Agrupando os estereótipos de acordo com as categorias indicadas anteriormente (quadro 3), verifica-se que as mulheres usam mais representações "militantes" $(77,8 \%)$ se comparadas aos homens $(57,4 \%)$. Entre os deputados, destaca-se o papel maternal da mulher, seu suposto companheirismo ou sua moralidade elevada.

Ainda tendo em vista tais grupos de estereótipos, a tabela 8 torna patente que os partidos de esquerda também dão maior realce aos estereótipos militantes, enquanto os partidos de centro e de direita se utilizam mais de representações conservadoras. Vale lembrar novamente que esta clivagem não pode ser atribuída apenas à maior quantidade de mulheres eleitas por partidos de esquerda, uma vez que mesmo entre os homens o viés de acordo com tendência partidária é perceptível. 
O Oito de Março no Congresso

Tabela 8: Grupos de estereótipos citados nos discursos de acordo com a posição partidária do parlamentar

\begin{tabular}{lcccc}
\hline & direita & centro & esquerda & Total \\
\hline \multirow{2}{*}{ "militantes" } & $55,4 \%$ & $52,4 \%$ & $78 \%$ & $\mathbf{6 2 , 7 \%}$ \\
& $(36)$ & $(33)$ & $(57)$ & $\mathbf{( 1 2 6 )}$ \\
\hline \multirow{2}{*}{ conservadores } & $83 \%$ & $82,5 \%$ & $42,5 \%$ & $\mathbf{6 8 , 1 \%}$ \\
& $(54)$ & $(52)$ & $(31)$ & $\mathbf{( 1 3 7 )}$ \\
\hline \multirow{2}{*}{ Total } & $\mathbf{1 0 0 \%}$ & $\mathbf{1 0 0 \%}$ & $\mathbf{1 0 0 \%}$ & $\mathbf{1 0 0 \%}$ \\
& $\mathbf{( 6 5 )}$ & $\mathbf{( 6 3 )}$ & $\mathbf{( 7 3 )}$ & $\mathbf{( 2 0 1 )}$ \\
\hline
\end{tabular}

Eram permitidas múltiplas respostas.

Foram excluídos desta tabela um discurso proferido por parlamentar "sem partido" no período.

Fonte: compilação dos autores

Dentre os pronunciamentos de homens há uma distribuição mais equânime entre a imagem do 8 de março como data comemorativa e de reflexão. Já no caso dos discursos de mulheres, existe uma maior concentração de menções ao dia da mulher como data de reflexão, conforme evidencia a tabela 9. Novamente, percebe-se mais uma importante diferença nas visões entre homens e mulheres no que tange às representações sobre a mulher e sua posição social.

Tabela 9: Relevância do dia da mulher de acordo com o sexo do parlamentar

\begin{tabular}{lccr}
\hline & feminino & masculino & \multicolumn{1}{c}{ Total } \\
\hline comemoração & $24,6 \%(29)$ & $36,7 \%(111)$ & $\mathbf{3 3 , 3 \% ( 1 4 0 )}$ \\
\hline reflexão & $59,3 \%(70)$ & $38 \%(115)$ & $\mathbf{4 4 \% ( \mathbf { 1 8 5 } )}$ \\
\hline não citado & $40,7 \%(48)$ & $39 \%(118)$ & $\mathbf{3 9 , 5 \% ( 1 6 6 )}$ \\
\hline Total & $\mathbf{1 0 0 \% ( \mathbf { 1 1 8 } )}$ & $\mathbf{1 0 0 \% ( 3 0 2 )}$ & $\mathbf{1 0 0 \% ( 4 2 0 )}$
\end{tabular}

Eram permitidas múltiplas respostas.

Fonte: os autores

Outra disparidade análoga se refere ao fato dos membros de partidos de esquerda discursarem mais sobre a importância da data para a reflexão (53,3\%), enquanto os percentuais são melhor 
distribuídos tanto na direita quanto no centro. Isso corrobora o que foi visto até o presente momento: que há uma série de afinidades eletivas entre os discursos das mulheres $e$ a esquerda política, bem como muitas semelhanças entre direita e centro quando o tema são as questões de gênero.

Além da quantidade relativa de ocorrências de determinadas representações sobre a mulher ou sobre o dia 8 de março, é fundamental ressaltar a presença de representações opostas nos mesmos discursos. Em 16,7\% dos discursos que citavam algum estereótipo houve a presença simultânea de estereótipos aqui classificados como opostos. Já em 18,9\% dos discursos que mencionavam alguma idéia sobre a relevância do dia 8 de março houve a presença simultânea das representações também classificadas em dois grupos de categorias opostos. Este dado ganha importância quando resgatamos uma das hipóteses levantadas no início do texto: a de que o cenário político atual é marcado pela memória das grandes mudanças na posição social das mulheres e, ao mesmo tempo, pela estagnação dos processos que levaram a estas mudanças. Apesar destes percentuais não serem altos, eles ajudam a confirmar esta hipótese, pois comprovam que a conciliação de representações da realidade em grande medida opostas não é rara.

\section{Conclusões}

A quase totalidade dos estudos sobre a participação política feminina tende a destacar a singularidade desta participação. As mulheres teriam uma ação diferenciada em praticamente todos os campos políticos: nos movimentos sociais, nos parlamentos, nos executivos, na burocracia etc. Qual seria a causa desta ação política aparentemente singular das mulheres é uma questão cujas respostas não contam com semelhante consenso.

É nítido que para autores que vêem a posição marginal da mulher na sociedade como fundadora de uma perspectiva social específica, a observação empírica da singularidade da ação 
O Oito de Março no Congresso

política feminina é entendida como uma decorrência mais do que esperada. Contudo, o fato das singularidades femininas serem perceptíveis nos mais diversos campos também embasa a visão de que a diferença feminina seria decorrência de algo mais permanente e profundo do que a marginalização social, como, por exemplo, uma sensibilidade especial.

Indagar quais seriam as causas originais das diferenças políticas entre homens e mulheres é uma interrogação que transborda os objetivos desta pesquisa. Não se pretendeu resolver o embate entre advogados da "política de perspectiva" e os defensores da "política do desvelo". 8 Entretanto, há que se destacar que um traço comum destes dois argumentos é que ambos tendem a buscar "fora" do campo político as explicações para as diferenças entre a ação política de homens e mulheres. Dito de outro modo, estas teorias políticas normativas tendem a relegar a um segundo plano as restrições impostas à ação política das mulheres pela própria estruturação do campo político.

As análises expostas aqui buscaram evidenciar que fatores internos ao campo político podem condicionar a emergência de determinados discursos. Não é suficiente destacar as peculiaridades da ação política em função do gênero, do mesmo modo que não é satisfatório justificar as demandas por representação política feminina observando somente como a constituição delas "fora" do campo político teria impacto dentro da política ou para a justiça social, genericamente falando.

As próprias relações de força dentro da política reconstituem as intenções e projetos dos agentes, o que marca a ação política $e$ estratégias deles. Além de mulheres, as deputadas são membros de um grupo minoritário no parlamento, são quase sempre vinculadas a partidos de tendência ideológica específica e possuem demandas de alcance social variável. Cada um destes fatores induz uma dada alteração na ação das parlamentares que

8 Sobre a questão, ver Miguel, 2001. 
não necessariamente tenha que ser explicada fazendo referência ao que seria a mulher ontologicamente.

A relativa ausência de abordagens feministas mais espinhosas e com maior possibilidade de acirrarem o conflito com os pares é exemplo de uma limitação imposta pelo próprio campo político às demandas femininas. É arbitrário dizer que a ausência de determinados debates se deva ao fato das mulheres parlamentares não se identificarem com estas temáticas. Mais problemática ainda é a defesa de rearranjos institucionais que visem privilegiar não as mulheres, mas as "mulheres feministas", como defendem Tremblay e Pelletier (2000:398). Antes, deve-se pensar nas outras relações em jogo na política, como a pressão de movimentos sociais, a necessidade estratégica de alianças com grupos mais conservadores ou o imperativo de não romper laços com a imagem do eleitorado construída pela parlamentar.

O descompasso detectado entre a difusão de determinadas questões nos movimentos feministas, de um lado, e a presença dos mesmos nos debates parlamentares, de outro, é um exemplo interessante de como estruturas típicas do campo político intervêm na ação dos que estão em seu interior.

Não falar sobre aborto, agressão contra a mulher ou submissão e desigualdades no mercado de trabalho é menos o efeito da baixa presença de mulheres do que dos custos políticos de discutir questões delicadas como estas. Prova disso é que enquanto menções à violência contra a mulher passaram de cinco ocorrências na $49^{\mathrm{a}}$ legislatura para 39 na $52^{\mathrm{a}}$, assuntos relacionados ao aborto foram praticamente silenciados (apesar de terem sido mencionados 6 vezes na $48^{\text {a }}$ legislatura, tiveram em média apenas uma menção por legislatura desde a $49^{\mathrm{a}}$ ). Como as referências ao aborto compreendem as legislaturas entre 1983 e 1995 podemos concordar que "de fato, com a redemocratização do país houve mudanças sobre a questão do aborto (...) sobretudo, na visibilidade do tema e na ampliação do debate" (Rocha, 2006). Todavia, esta ampliação do debate parece ter sido pontual. Logo, se falar da violência contra a mulher não é mais 
O Oito de Março no Congresso

tão arriscado, o mesmo não pode ser dito quando o assunto se refere aos direitos reprodutivos, que facilmente geram inimizades e podem levar ao rompimento de laços com eleitores históricos.

Outro ponto importante é o fato da esquerda política estar muito mais sintonizada com as causas das mulheres do que os partidos de centro ou de direita. Assim sendo, vale questionar até que ponto a esquerda arcaria com menos riscos políticos ao tocar em questões críticas do que as outras duas tendências ideológicas. Em geral, os dados comprovaram que a quantidade relativa de discursos sobre o tema, de assuntos citados e de estereótipos mencionados é muito semelhante quando comparamos os partidos de centro (MDB, PMDB e PSDB) com os de direita.

Isto tem muita importância quando lembramos que parte significativa da literatura sobre o feminismo realça a migração de feministas para o PMDB e o PSDB no período que engloba a realização da Assembléia Constituinte. Estas legendas, juntamente com o PT, teriam sido as com maior penetração de feministas históricas e, conseqüentemente, de temáticas feministas (Pinto, 2003:72). É de se supor que, apesar disso, a posição política dos partidos de centro coloque barreiras específicas às temáticas de gênero, diferentes das existentes na esquerda política.

É claro que os dados não permitem afirmar conclusivamente que os partidos de centro não sejam tão "feministas" quanto os de esquerda. Para tal, seria necessário uma análise mais profunda, que incluísse os projetos de leis ou o posicionamento dos partidos frente a determinadas questões. No entanto, partindo do pressuposto que o maior ou menor espaço para discursos $e$ temáticas feministas na Câmara dos Deputados serve como índice da posição partidária frente às questões de gênero, pode-se enquadrar sim tanto o PSDB quanto o PMDB em uma posição "não-feminista" ou "menos-feminista" do que as análises históricas poderiam indicar.

Ao que parece, partidos que se destacaram por abrigar grandes nomes do feminismo deram vazão às demandas feministas de maneiras diversas e em tempos diferentes. Mais uma 
vez, é possível explicar as singularidades da ação política das mulheres adicionando uma análise das próprias estruturas políticas.

Verificou-se também que o cenário político atual induz à junção de visões opostas sobre a mulher e sobre as suas lutas num mesmo pronunciamento. Isto ficou nítido quando observamos a presença simultânea de representações sobre a mulher e sobre o seu dia nos discursos. Observa-se aí a influência de uma necessidade típica da política eleitoral: a de aumentar a base de legitimidade, atingindo através do discurso a parcela mais ampla possivel dos eleitores:

A mulher, não por beneficência da lei, mas por seus méritos pessoais, tem conquistado na sociedade, nos setores público e privado, o espaço digno da sua competência, da sua dedicação e da sua lealdade. Mas, Sr. Presidente, por mais elogiosos que sejam os discursos em homenagem à mulher nesta e na outra Casa do Congresso Nacional, não conseguimos dar à mulher o maior presente que ela merece: o fim da prostituição, de uma vez por todas. Ainda há mulheres que se prostituem por não terem oportunidade de encontrar emprego para garantir o sustento de sua família. E pior: ainda há mulheres que são espancadas em seus lares, $e$ infelizmente nossas leis ainda não punem exemplarmente os maridos e companheiros que praticam esse tipo de delito. A mulher, enfim, ainda é discriminada (Deputado Roland Lavigne, do PMDB-BA, 8/3/2002, ênfase acrescentada).

Hoje se comemora o Dia Internacional da Mulher, e não poderíamos, em hipótese alguma, deixar de vir a esta tribuna para prestar nossa humilde, mais sincera homenagem àquela que é responsável pelo ser humano, a mulher, que guarda um ser no seu ventre durante nove meses, que o acaricia, ainda que internamente, e depois o acalenta; a mulher mãe, que sabe dar carinho $e$ amor, que sabe reprimir, mas, sobretudo, preparar o ser humano para a vida. Quero homenagear a mulher operária, que, com o 
O Oito de Março no Congresso

suor do rosto, ajuda o companheiro a manter a família. Rendo minha homenagem à mulher companheira, esposa, aquela que divide no lar os anseios, os sofrimentos, as alegrias e que, muitas vezes, colhe as migalhas para dar alimento a seus filhos, freqüentemente realizando a multiplicação dos pães (Deputado Asdrubal Bentes, do PMDBPA, 8/3/2002, ênfase acrescentada).

Este é um dia de festa e de homenagens à mulher. (...) Este é um dia de festa, insisto, mas principalmente de profundas reflexões (Deputada Simara Ellery, do PMDB-BA, 8/3/1995, ênfase acrescentada).

O primeiro trecho não privilegia representações otimistas ou pessimistas sobre a realidade, mas sim, as une numa relação de complementaridade. Algo semelhante ocorre com os estereótipos citados no segundo excerto. Já no terceiro, ocorre uma oscilação, uma mudança de ênfase. Logo, não existe a polarização dos discursos: em vez de marcarem posições e se confrontarem, os discursos possuem em seu interior visões opostas sobre a mulher $e$ sua situação. Predomina a tentativa de atingir dois públicos diversos, um "mais ou menos" crítico e outro "mais ou menos" exultante da situação social da mulher.

Só é possível casar estereótipos e visões sobre as desigualdades de gênero graças à própria conformação do debate político, que passa ao largo de questões que suscitam conflito $e$ polêmica. Destaque para a quase completa ausência das menções aos direitos reprodutivos, discussão já antiga do feminismo, mas ainda muito polêmica e cuja menção per se implica uma tomada de posição.

Toda teoria ou movimento social que demande a inclusão de representações sociais historicamente marginalizadas na representação política deve questionar quais os limites impostos a esta inclusão pelas próprias dinâmicas do campo político e em que medida algumas alterações nestes ainda seriam necessárias. Obviamente, alguns problemas sociais atingem mais diretamente as mulheres e é de se supor que uma maior presença delas leve a 
uma maior discussão pública destas questões. Contudo, as necessidades externas e internas, típicas do campo político, impõem uma determinada ordem aos discursos, importante para qualquer estudo sobre participação política e gênero. A esperança de uma mudança das arenas políticas formais a partir da entrada de novos atores não pode desconhecer os efeitos potenciais destas arenas na transformação destes atores.

\section{Referências bibliográficas}

ARAúJO, Clara. Partidos políticos e gênero: mediações nas rotas de ingresso das mulheres na representação política. Revista de Sociologia Política (24), São Paulo, 2005, pp. 193-215.

BLAY, Eva. 8 de março: conquistas e controvérsias. Revista Estudos Feministas 9(2), Florianópolis, 2001.

CHODOROW, Nancy. The reproduction of mothering. Berkeley, University of California Press, 1978

Costa, Claudia. Paradoxos do gênero. Gênero 4(1), Niterói, 2003, pp. 169-78.

DELPHY, Christine. Feminismo e recomposição da esquerda. Revista Estudos Feministas 2(1), Florianópolis, 1994, pp. 187-99.

ElSHTAIN, Jean. Public man, private woman. Princeton, Princeton University Press, 1981.

GILLIGAN, Carol. In a different voice: psychological theory and woman's development. Cambridge (MA), Harvard University Press, 1982.

GIUMBELLI, Emerson. Para além do "trabalho de campo": reflexões supostamente malinowskianas. Revista Brasileira de Ciências Sociais (48), São Paulo, 2002, pp. 96-7.

JODELET, Denise. As Representações Sociais. Rio de Janeiro, EDUERJ, 2001.

MIGUEL, Luis Felipe. Teoria política feminista e liberalismo: o caso das cotas de representação. Revista Brasileira de Ciências Sociais (44), São Paulo, 2000, pp 91-102. 
O Oito de Março no Congresso

Política de interesses, política do desvelo: representação e "singularidade feminina". Revista Estudos Feministas 9(1), 2001, pp. 253-67.

. Representação política em 3-D: elementos para uma teoria ampliada da representação política. Revista Brasileira de Ciências Sociais 18(51), São Paulo, 2003, pp 123-140.

OHIRA, Aline Marques; FeITOSA, Fernanda; CAMPOS, Luiz Augusto. Falas femininas no Congresso: gênero e nichos discursivos na Câmara dos Deputados. Paper apresentado no VII Seminário Internacional Fazendo Gênero. Florianópolis, 2006.

NICHOLSON, Linda. Interpretando o gênero. Revista Estudos Feministas 8(1), Florianópolis, 2000, pp. 9-42.

PHILLIPS, Anne. De uma política de idéias a uma política de presença? Revista Estudos Feministas 9(1), Florianópolis, 2001, pp. 268-90.

PINTO, Celi. Uma história do feminismo no Brasil. São Paulo, Fundação Perseu Abramo, 2003.

PITKIN, Hanna. The Concept of Representation. Berkeley, University of California Press, 1967.

RochA, Maria. A questão do aborto no Brasil: discussões e decisões no âmbito da sociedade e do Estado (uma síntese). Paper apresentado no VII Seminário Internacional Fazendo Gênero, Florianópolis, 2006.

RUDDICK, Sara. Maternal thinking: towards a politics of peace. Boston, Beacon Press, 1989

ScotT, Joan. Gênero: uma categoria útil de análise histórica. Educação e Realidade 16(2), Porto Alegre, 1990, pp. 5-22.

TREMBLAY, Manon; PELlETIER, Réjean. More feminists or more women?: descriptive and substantive representations of women in the 1997 Canadian federal elections. International Political Science Review 21(4), Guildford, 2000, pp. 381-405.

VARIKAS, Eleni. Naturalização da dominação e poder legítimo na teoria política clássica. Revista Estudos Feministas 11(1), Florianópolis, 2003, pp. 171-93.

YOUNG, Iris Marion. Representação política, identidade e minorias. Lua Nova (67), São Paulo, 2006, pp. 139-90. 